\title{
Ecosystem-Based Management in the Arctic Ocean: A Multi-Level Spatial Approach
}

\author{
ROBERT SIRON, ${ }^{1}$ KENNETH SHERMAN, ${ }^{2}$ HEIN RUNE SKJOLDAL ${ }^{3}$ and ELIZABETH HILTZ ${ }^{4}$
}

(Received 26 June 2007; accepted in revised form 11 January 2008)

\begin{abstract}
Ecosystem-based management (EBM) first requires the identification of spatial units capturing the ecosystem structure and functions. To this end, the Arctic Council has adopted the Large Marine Ecosystem (LME) framework. Ecosystem experts have identified 17 Arctic LMEs and mapped them for monitoring and assessment purposes. We provide an overview of their major ecological features. The ecosystem approach has also been developed nationally, with EBM initiatives undertaken as part of the national ocean policy frameworks and actions plans of the United States and Canada. A case study of the Beaufort Sea Large Ocean Management Area (LOMA) established for integrated ocean management purposes shows how Canada's national spatial framework is being implemented at the subregional level. A comparison of this framework to the international LME that overlaps it in the Canadian waters of the Beaufort Sea demonstrates that both approaches are based on the same principles and criteria, and aim at the same goal: giving primary consideration to the marine ecosystem when managing activities. The two approaches are complementary because they are applied at different spatial and governance levels: regional (Arctic-wide) and subregional (in Canadian Arctic waters). A multi-level spatial framework, science-based management tools, and a governance structure are now available to managers in the Beaufort Sea pilot region; now managers must put in the effort needed to make EBM operational and address the complex environmental issues facing the Arctic.
\end{abstract}

Key words: ecosystem approach, ecosystem-based management, integrated management, spatial scale, Arctic Ocean, Large Marine Ecosystems, Large Ocean Management Area, Beaufort Sea

RÉSUMÉ. La gestion basée sur l'écosystème (GÉ) requiert tout d'abord l'identification d'unités spatiales qui capturent la structure et les fonctions de l'écosystème. À cette fin, le concept des Grands écosystèmes marins (GEM) a été adopté par le Conseil de l'Arctique et 17 GEM ont été identifiés et cartographiés dans l'océan Arctique aux fins de monitorage et d'évaluation. Un aperçu des principales caractéristiques écologiques de ces GEM est donné. L'approche écosystémique est aussi développée nationalement : les initiatives de GÉ entreprises par les États-Unis et le Canada dans le cadre de leurs politiques nationales et plans d'actions pour les océans sont décrites. La zone étendue de gestion des océans (ZÉGO) de la mer de Beaufort établie pour les besoins de la gestion intégrée des océans a été prise comme étude de cas pour montrer comment le cadre national est mis en œuvre au niveau subrégional au Canada. Puis, nous avons rassemblé l'information pertinente et comparé les deux cadres spatiaux, GEM et ZÉGO, qui se chevauchent dans les eaux canadiennes de la mer de Beaufort. Cette étude démontre que les deux approches appliquées à des niveaux complémentaires - régional (à la grandeur de l'Arctique) et subrégional (dans les eaux canadiennes de l'Arctique) - sont convergentes car elles sont basées sur les mêmes principes et critères, et visent le même but : considérer en premier lieu l'écosystème marin lors de la gestion des activités. Un cadre spatial à niveaux multiples, des outils de gestion basés sur la science et une structure de gouvernance sont maintenant disponibles pour la gestion dans la région pilote de la mer de Beaufort; il s'agit maintenant de mettre l'effort nécessaire pour rendre la GÉ opérationnelle et aborder les enjeux environnementaux complexes auxquels l'Arctique fait face.

Mots clés : approche écosystémique, gestion écosystémique, gestion intégrée, échelle spatiale, océan Arctique, Grands écosystèmes marins, zones étendues de gestion des océans, mer de Beaufort

\section{INTRODUCTION}

The growing demand for ocean resources has augmented the number of human activities that, in turn, increase the risk of cumulative impacts on marine ecosystems. The cumulative impact of anthropogenic pressures such as climate change, pollution, and overfishing is of great concern in the polar regions, where marine ecosystems already face extreme environmental conditions (Clarke and Harris, 2003). This situation applies to the Arctic

\footnotetext{
${ }^{1}$ Oceans Directorate, Oceans Policy and Planning Branch, Fisheries and Oceans Canada, 200 Kent Street, Ottawa, Ontario K1A 0E6, Canada; robert.siron@dfo-mpo.gc.ca

${ }^{2}$ Narragansett Laboratory, Northeast Fisheries Science Center, National Oceanic and Atmospheric Administration, 28 Tarzwell Drive, Narragansett, Rhode Island 02882, USA; kenneth.sherman@noaa.gov

${ }^{3}$ Institute of Marine Research, PO Box 1870, Nordnes, N-5817 Bergen, Norway; hein.rune.skjoldal@imr.no

${ }^{4}$ Oceans Programs, Central and Arctic Region, Fisheries and Oceans Canada, Freshwater Institute, 501 University Crescent, Winnipeg, Manitoba R3T 2N6, Canada; beth.hiltz@dfo-mpo.gc.ca

(c) The Arctic Institute of North America
} 
Ocean, where early signs of global warming (ACIA, 2004) and significant levels of persistent bio-accumulating pollutants (UNEP, 2006) are superimposed on local stressors. Climate change impacts are expected to be greater in the Arctic than in any other region and will result in important socioeconomic changes. For example, future scenarios of climate change predict a reduction of the Arctic ice cover that will certainly lead to a significant increase in shipping, with new or enhanced harbour infrastructures and facilities built on Arctic coasts (Brigham and Ellis, 2004). In addition to marine transportation, traditional activities like fishing and hunting, a reactivation of the oil and gas industry in the offshore zone, and emergent sectors like tourism have the potential to affect Arctic ecosystems as never before. Moreover, coastal areas are under the influence of land-based activities and freshwater discharges. Together, these anthropogenic pressures will put the fragile balance of the Arctic marine environment under great stress (Fortier and Fortier, 2006). Marine ecosystems and the interactions both among their components and with human activities are extremely complex. To capture those complex relationships, and to assess and manage the human impacts so as to ensure ecosystem conservation and sustainable development in the Arctic, a holistic approach is needed.

The Ecosystem-Based Management (EBM) approach is inseparable from the concept of ecosystem health, which in turn is critical to ensuring sustainable use of natural resources for provision of ecosystem goods and services (Rapport et al., 1998). It is wise to keep in mind that, although some ecosystem goods (e.g., fisheries or aquaculture) have significant economic value, ecosystem services (including cultural heritage and spiritual benefits) are undervalued most of the time and are typically not considered in policy decisions (McLeod et al., 2005). We need healthy marine ecosystems to maximize social, cultural, and economic benefits from ocean-related activities. Marine ecosystem health may be assessed by looking at ecosystem properties (those ecological properties that are emergent, and potentially measurable, at the ecosystem level): organization, vigor, and resilience of the ecosystem. This overarching concept is more relevant to ocean policies and operational management frameworks if expressed as the need to maintain marine ecosystem structure (e.g., biodiversity), functions (e.g., productivity), and processes (e.g., energy flow) to ensure resilient and healthy marine ecosystems.

The international community, through a series of international treaties and policy documents, has committed itself to promoting and implementing EBM as a guiding principle for ocean management within the sustainable development context (for a comprehensive review of international initiatives, see Wang, 2004a). Several countries have also made the ecosystem-based integrated management approach a core piece of their modern, nationally implemented ocean policy frameworks. Among the countries that have interests in the Arctic, Canada, the
United States, and Norway are certainly the most advanced in terms of developing and implementing a national approach for ecosystem-based management of ocean uses, spaces, and resources. Norway has committed to developing an ecosystem approach to management in its adjacent seas (Anon., 2002). For example, a collective effort has been made to report on the state of the Norwegian Sea ecosystem (Skjoldal, 2004), and EBM has been implemented in the Barents Sea and areas off the Lofoten Islands (Anon., 2006; Olsen et al., 2007). Since this paper focuses on the Beaufort Sea area as a case study for EBM implementation, the ocean policy networks for both the United States and Canada will be further detailed.

Two parallel and independent processes aim to implement an ecosystem-based approach to ocean management within Canada's Arctic waters. The geographical scale and spatial context of the EBM implementation are the main points discussed in this paper. At the national level, an EBM framework has been developed for years and is being applied to a significant part of the Canadian Arctic, i.e., the Beaufort Sea. At the circumpolar (regional) level, the concept of Large Marine Ecosystems (LMEs) developed by the United States and applied worldwide has been adopted by the Arctic Council's Protection of the Arctic Marine Environment (PAME) Working Group (www.arctic portal.org/en/pame) as the appropriate framework for advancing the ecosystem approach in the whole Arctic region. Both processes have achieved the first step, the characterization of marine ecosystems and delineation of relatively large ecological units that provide the spatial and functional context for planning ocean management based on ecosystem considerations. Cash et al. (2006) suggest that success in assessing problems and finding politically and ecologically sustainable solutions is greater when a complex system that consciously addresses scale issues and the dynamic linkages across levels is used. Here we use those ecological units delineated at various levels for EBM purposes in Canadian Arctic waters to evaluate how complementary and effective this multi-level spatial approach could be.

\section{EBM AT THE GLOBAL LEVEL: THE LME APPROACH}

\section{LME Strategy and Geography}

The LME approach to assessment and management of coastal and ocean marine ecosystems goods and services is a five-module strategy for measuring changes in ecosystems (Fig. 1). Governments use information on the changing states of LMEs to improve marine resource management practices and move toward restoration of degraded habitats, reduction of coastal pollution, and recovery of depleted fish stocks. At present, there is a global movement to introduce and practice EBM of marine resources in partnerships with the Global Environment Facility (GEF) as a funding mechanism (www.undp.org/gef). The 
International Union for the Conservation of Nature and Natural Resources (IUCN), the Intergovernmental Oceanographic Commission of UNESCO (IOC), and several other United Nations organizations act as executing and implementing agencies.

Governments, as well as a broad constituency in the scientific community, are endorsing and supporting the LME strategic approach nationally and internationally. The strategy provides an incremental, place-based structure for marine ecosystem monitoring, assessment, and management in GEF-funded LME projects presently underway in Africa, Asia, Latin America, eastern Europe, and the Arctic (Duda and Sherman, 2002). LMEs are natural regions of coastal ocean space encompassing waters from river basins and estuaries and extending to the seaward boundaries of continental shelves and outer margins of coastal currents and water masses. They are relatively large regions, $200000 \mathrm{~km}^{2}$ or more, characterized by distinct bathymetry, hydrography, productivity and trophically dependent populations (Sherman, 1994; Duda and Sherman, 2002; www.lme.noaa.gov/Portal/). Together, the world's 64 LMEs account for $90 \%$ of the annual global yield of marine fisheries (Garibaldi and Limongelli, 2003). They also have the highest global levels of primary production and productivity, as estimated from SeaWiFS satellite data (Behrenfeld and Falkowski, 1997), the most severe degradation of marine habitats, concentrations of coastal pollution, and increasing levels of eutrophication (GESAMP, 2001). Other LME characteristics that may have implications for their management can be found in Wang (2004a).

\section{LME Funding}

Since 1995, the GEF has provided substantial funding to support country-driven projects for introducing multisectoral, ecosystem-based assessment and management practices for LMEs. At present, 121 developing countries are preparing and implementing GEF-LME projects, with a total of US $\$ 650$ million in start-up funding. The GEF Council has approved 10 projects involving 70 countries, and another seven international waters projects, involving 51 countries, are in preparation (www.iwlearn.net). In Africa, two major projects to manage marine resources from an LME perspective are underway: the Benguela Current Commission, with three countries participating, and the Interim Guinea Current Commission, which involves 16 countries. The Beijing Ministerial Declaration incorporating the LME approach was approved at the Second Intergovernmental Review Meeting of the Global Programme of Action for the Protection of the Marine Environment from Land-based Activities (GPA), under the United Nations Environment Programme (UNEP), held in Beijing in October 2006. An innovative partnership between GEF and the World Bank recently created the billion-dollar Investment Fund for Pollution Reduction in the East Asia LME. Similar partnerships began in 2006 in the Mediterranean Sea LME and coastal countries of sub-Saharan Africa.

\section{LME Monitoring and Assessment: Indicator Modules}

All GEF LME projects incorporate the five-module indicator approach to monitoring, assessment, and management discussed above (Fig. 1). Three of the five modules, productivity, fish/fisheries, and pollution/ecosystem health, apply science-based indicators that depend on time-series monitoring of LMEs. Suites of indicators to monitor changing conditions in LMEs are under development (Sherman and Hempel, in press). The socioeconomics and governance modules focus on benefits to be gained from a more sustainable resource base and from providing stakeholders and stewardship interests with legal and administrative support for EBM practices. The modules are adapted to LME conditions through a transboundary diagnostic analysis (TDA) process to identify key issues, and a strategic action program (SAP) development process for the groups of nations or smaller administrative units sharing the LME (Fig. 2). These processes are critical for the practical integration of science into management and for determining appropriate governance regimes (Wang, 2004b). The first four modules support the TDA process, whereas the governance module is associated with periodic updating of the SAP development process. Adaptive management regimes are encouraged through periodic assessments (TDA updates) and by updating the action programs as gaps are filled (Fig. 2).

\section{EBM AT THE REGIONAL LEVEL: ARCTIC LMES}

The ecosystem approach is the key principle proposed to meet the long-term goals of the Arctic Council's Arctic Marine Strategic Plan: to reduce and prevent pollution, conserve marine biodiversity and ecosystem functions, promote the health and prosperity of Arctic inhabitants, and advance sustainable marine resource use (Arctic Council, 2004). A group of ecosystem experts of the Arctic Council's PAME Working Group delineated LMEs in the Arctic using the best ecosystem knowledge available, and in 2006 the Arctic Council adopted a working map of 17 designated LMEs in the Arctic Ocean (Fig. 3). As a follow-up, the same ecosystem experts have been asked to (1) develop suites of indicators based on the five-module framework for assessing and monitoring changing states of Arctic LMEs, particularly in relation to reduced Arctic ice cover, (2) report on the Arctic LMEs, and (3) develop pilot LME projects for advancing the EBM approach in the Arctic.

The working map of the 17 Arctic LMEs represents the spatial framework for further work and planning in the Arctic Ocean. For example, this ecological basis has been used to assess the status and vulnerability of Arctic ecosystems in relation to oil and gas activities under the 


\title{
Modular Assessments for Sustainable Development
}

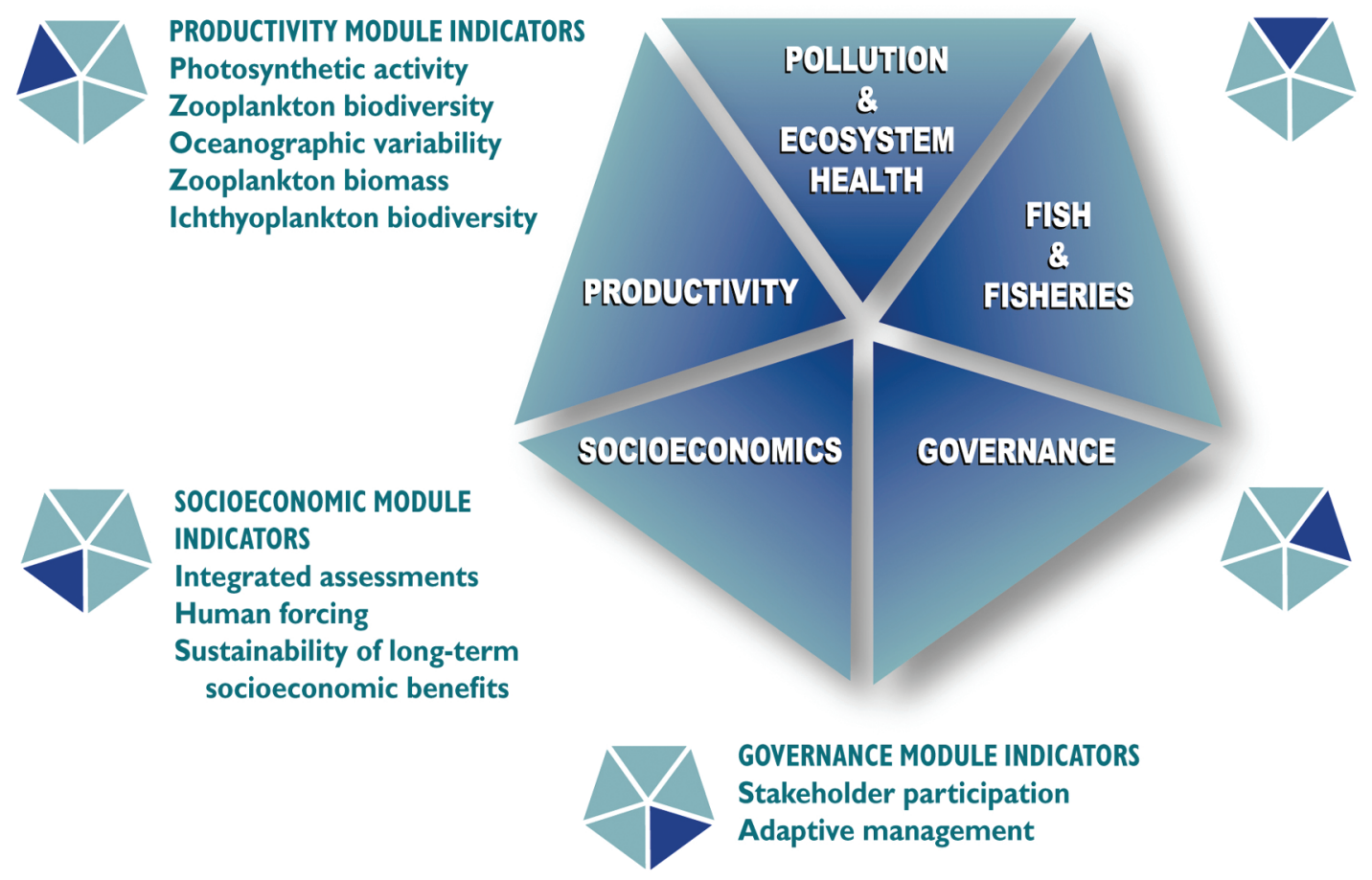

\author{
POLLUTION \& ECOSYSTEM \\ HEALTH MODULE INDICATORS \\ Eutrophication \\ Biotoxins \\ Pathology \\ Emerging disease \\ Health indices \\ Multiple marine ecological \\ disturbances
}

FISH \& FISHERIES MODULE
INDICATORS
Biodiversity
Finfish
Shellfish
Demersal species
Pelagic species

FIG. 1. Large marine ecosystem (LME) modules as suites of condition indicators.

leadership of the Arctic Council's Arctic Monitoring and Assessment Programme (AMAP) working group (www.amap. no.oga). The AMAP oil and gas assessment report will inform policy development and management decisions in relation to oil and gas activities in Arctic waters. The ongoing Arctic Marine Shipping Assessment led by PAME will also use Arctic LMEs as geographic regions in which to measure environmental impacts of shipping activities (AMSA, 2006).

The 17 Arctic LMEs span a latitudinal range from about $52^{\circ} \mathrm{N}$ (James Bay in Hudson Bay and the southernmost Aleutian Islands) to the North Pole (Fig. 3). Physical and ecological conditions vary widely across the 17 LMEs. Deep basins $(3.5-4 \mathrm{~km})$ are found in the Arctic Ocean, West Bering Sea, Norwegian Sea, and Greenland Sea LMEs, with somewhat shallower basins $(1.5-2 \mathrm{~km})$ in the Iceland Sea/Shelf and Baffin Bay-Davis Strait LMEs. The remaining 11 LMEs are mainly shelf regions that have quite different geological and physiographic configurations. The widest shelves are generally found on the Eurasian part of the Arctic Ocean.

The North Pacific and North Atlantic oceans are connected with the Arctic Ocean via the Bering Sea and the Nordic seas. Atlantic water flows as an intermediate layer between depths of about 200 and $1000 \mathrm{~m}$, overlain by the lighter (less salty) Pacific waters in the Canadian Basin. Most of the Pacific waters exit through the Canadian Arctic Archipelago, whereas most of the Atlantic waters exit through the Fram Strait into the Greenland Sea.
Characteristic features of many Arctic marine ecosystems are the presence of ice, either permanent or seasonal, large freshwater inputs, and pronounced vertical stratification of the water column. In dynamic zones where strong forces may be at play, leads may open and recurrent polynyas may occur. Some polynyas may be very large, reaching over $1000 \mathrm{~km}$ in length. Polynyas also occur where mixing causes warmer water from a subsurface layer to be brought to the surface. Polynyas are important for ocean-atmosphere heat exchange because they are ice-free areas.

The number of species of plants and animals generally decreases from the boreal through the Subarctic to the High Arctic zone. This gradient reflects the increasingly harsh environment: high seasonal variability, a long winter, a short productive season, and limited primary production constrain the species adapted to live in the Arctic. Production is limited by a short growing season (due to the presence of ice during spring and early summer), low nutrient content in surface waters, and strong density stratification from ice melt. In certain cases, however, the very high rate of primary production supports high secondary production and large populations at higher trophic levels. The number of truly endemic High Arctic species is limited; most species of plankton and benthos are widely distributed from the boreal or Subarctic areas into the High Arctic. For the benthos, the highest numbers of endemic Arctic species occur in the deep basins of the Arctic Ocean and in coastal shallow-water areas with brackish conditions in the freshwater discharge from large Arctic rivers. 


\section{PLANNING ACTIONS}

1. Transboundary Diagnostic Analysis (TDA) - provides consensus priorities from analysis and ranking of water-related resources issues, their environmental and socioeconomic impacts, immediate and root causes and possible remedies

2. Strategic Action Program (SAP) - provides national and regional commitments to policy, legal and institutional reforms, and investments to remedy root causes of priority transboundary issues identified in TDA

\section{IMPLEMENTATION ACTIONS}

\section{Ecosystem-based assessment and management strategy for} TDA and SAP

3.1 Productivity indicators and assessments

3.2 Fish and fisheries indicators and assessments

3.3 Pollution and ecosystem health indicators and assessments

3.4 Socioeconomic indicators and assessments

3.5 Governance indicators and assessments

Integrated EcosystemBased Assessment and Adaptive Management

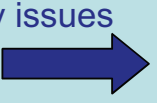

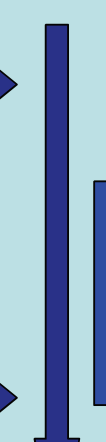
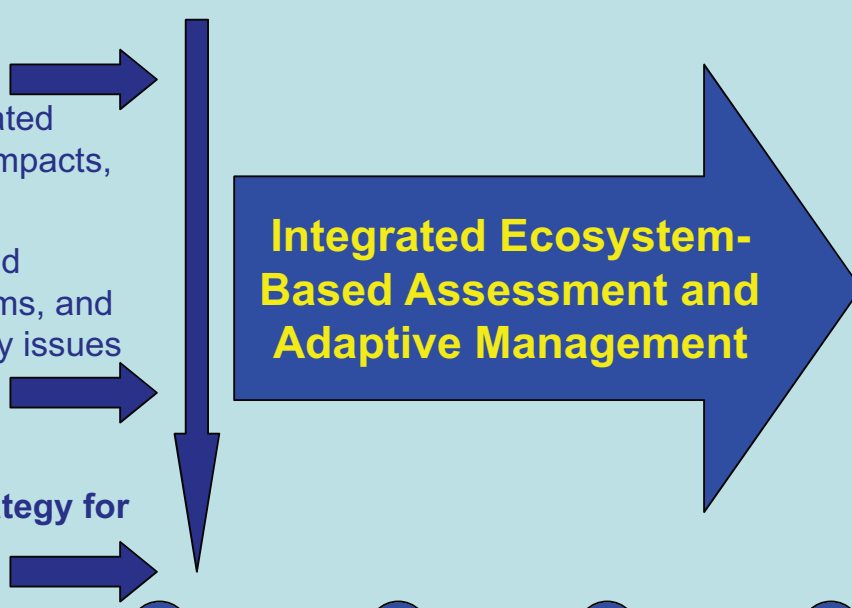


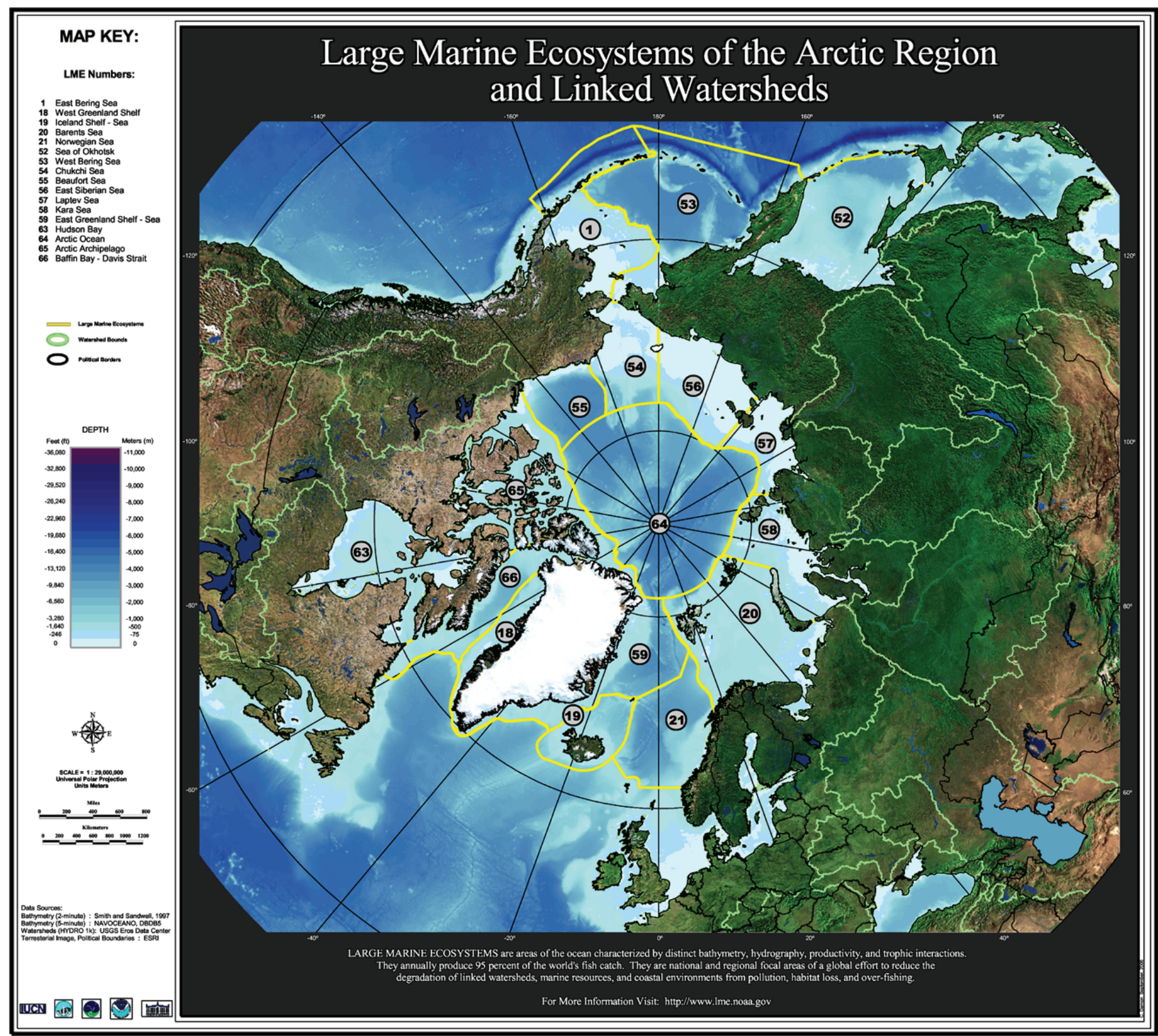

FIG. 3. Working map of the 17 large marine ecosystems (LMEs) identified in the Arctic by the LME experts group.

mandated by the U.S. Congress and carried forward by 16 members appointed by the President, held public meetings, made site visits, and based its recommendations on the advice received from hundreds of people across the country. The Commission's final report highlights the progress that has been made, while also identifying key recommendations for advancing ocean, coastal, and Great Lakes policy. The report emphasizes ecosystem assessment and management. Chapter 3, Setting the Nation's Sights, recommends sustainability, stewardship, oceanland-atmosphere connections, ecosystem-based management, multiple-use management, and other general policies. Further, the section entitled Translating Principles into Policy, under the subheading Ecosystem-based Management, reads as follows:
Sound ocean policy requires managers to simultaneously consider the economic needs of society, the need to protect the nation's oceans and coasts, and the interplay among social, economic, and ecological factors. These factors are closely intertwined, just like the land, air, sea, and marine organisms. Activities that affect the oceans and coasts may take place far inland, for example, landbased sources of pollution, such as runoff from farms and city streets, are a significant source of the problems that plague marine ecosystems. Ocean policies cannot manage one activity, or one part of the system, without considering its connections with all the other parts. Thus, policies governing the use of US ocean and coastal resources must become ecosystem-based, science-based, and adaptive.

(USCOP, 2004:33) 
In the introduction to the OAP, the Administration clearly states that it "will continue to work toward an ecosystem-based approach in making decisions related to water, land and resource management..." (USOAP, 2004:3). These policy statements are in keeping with the 20-year development of the LME approach to the assessment and management of marine resources and their environments, both within the waters of the 10 LMEs along the U.S. coasts and in partnerships with United Nations agencies and developing nations in Africa, Asia, Latin America, and Eastern Europe. The EBM strategy of the Commission for Ocean Policy is emphasized in the U.S. Ocean Action Plan, which supports the use of LMEs in the section on Advancing International Oceans Science (USOAP, 2004:36-37):

The U.S. will promote, within the United Nations Environment Program's regional seas programs and by international fisheries bodies, the use of the Large Marine Ecosystems (LME) concept as a tool for enabling ecosystem-based management to provide a collaborative approach to management of resources within ecologically bounded transnational areas. This will be done in an international context and consistent with customary international law as reflected in 1982 UN Convention on the Law of the Sea.

\section{Canada's Integrated Ocean Management and the EBM Framework}

Management of activities within Canadian marine waters has developed on a sectoral or regional basis and is therefore diverse and not always as integrated and coordinated as it should be. For example, there are about 50 federal statutes directly affecting activities in oceans and over 80 provincial laws affecting coastal and marine planning (Mageau et al., 2005). The Oceans Act (1996) is really the starting point for Canada's federal government to develop a nationally coherent ocean policy framework. The act provides the broad context for the development of an ecosystem approach for marine ecosystem conservation and stresses the importance of maintaining biological diversity and productivity in the marine environment. It also constitutes a mandate to develop related programs and regulatory instruments: integrated management (IM) of human activities in oceans, designation of marine protected areas (MPAs), and development of marine environmental quality objectives, guidelines, standards, criteria, and requirements. In addition, the act calls for the development of an overarching strategy for ocean management: Canada's Oceans Strategy (COS, 2002a) was developed after a broad public consultation process and is based on three key principles: (1) integrated management, (2) sustainable development, and (3) the precautionary approach. Its overall goal is "to ensure healthy, safe and prosperous oceans for the benefit of current and future generations of Canadians" (COS, 2002a:10). The Strategy's companion document (COS, 2002b) provides a policy and operational framework for integrated management of human activities in Canada's oceans and coastal environments. EBM and ecosystem conservation are core principles within the IM framework. The Department of Fisheries and Oceans (DFO) is the lead federal department with the mandate to coordinate the development of a cohesive ocean strategy and policy framework.

In 2004, the Government of Canada committed to a twoyear (2005-07) Oceans Action Plan (OAP) to achieve a series of deliverables grouped under four thematic pillars: (1) International Leadership, Sovereignty and Security, (2) Integrated Management for Sustainable Development, (3) Health of the Oceans, and (4) Ocean Science and Technology (OAP, 2005). The ecosystem approach is the core principle within pillars 2 and 3 of the Plan. A number of key deliverables identified within the Plan were to advance the EBM approach. Under Health of the Oceans, the Plan was directed to designate MPAs and develop a federal strategy for the establishment of a network of MPAs. These initiatives will help Canada meet its international commitments in terms of marine biodiversity and ecosystem conservation. Within the Integrated Management pillar, the Plan identified five priority Large Ocean Management Areas (LOMAs) in the three oceans contiguous with Canada: 1) Eastern Scotian Shelf, (2) Gulf of St. Lawrence, (3) Placentia Bay-Grand Banks, (4) Pacific North Coast, and (5) Beaufort Sea. These LOMAs have served as pilots to test and apply science-based management tools specifically developed for advancing and implementing EBM. The Beaufort Sea LOMA initiative is detailed in the next section to illustrate this implementation at the subregional scale.

The OAP also identified a number of key deliverables that would enhance the knowledge of marine ecosystems and help identify conservation priorities within the five LOMAs: (1) the preparation of ecosystem overview and assessment reports (EOARs) on marine ecosystems nested within the management areas, (2) the identification of ecologically and biologically significant areas (EBSAs), and (3) the development of ecosystem objectives for informing IM plans in LOMAs. These science-based management tools are needed to achieve key steps of integrated ocean management (Fig. 4). They are the "building blocks" on which the EBM framework has been developed in Canada (Fig. 5). Overall, this hierarchy of nested frameworks agrees with the vision of the Convention on Biological Diversity, which described the ecosystem approach as a strategy for the integrated management of land, water, and living resources that promotes conservation and sustainable use in an equitable way (CBD, 2000).

\section{EBM Framework for Integrated Ocean Management}

In the Canadian marine context, the EBM approach can be defined operationally as one that makes marine ecosystem health its primary consideration in managing human 


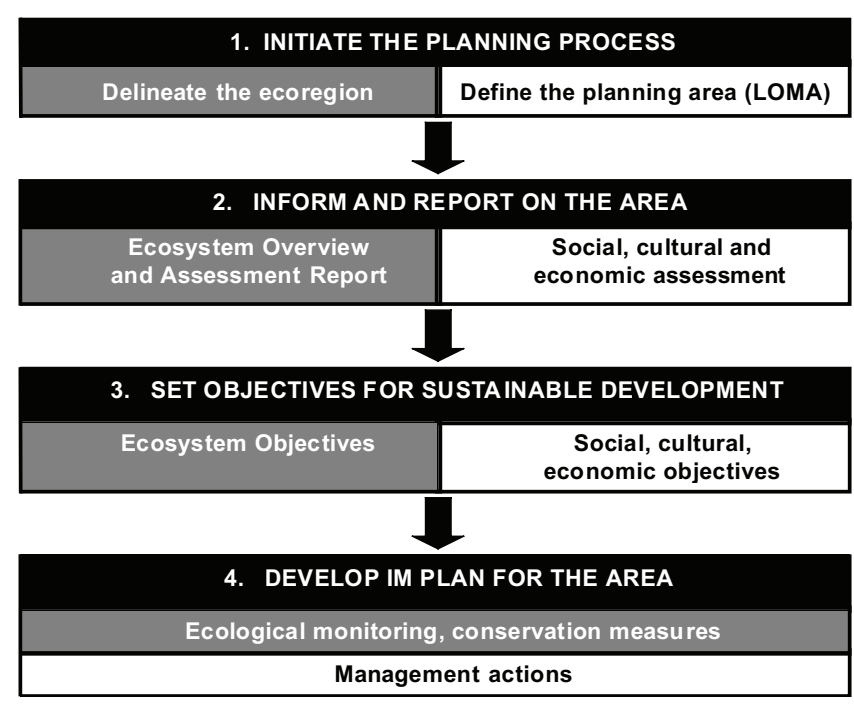

FIG. 4. Key steps for implementing integrated management (IM) in Canada's large ocean management areas (LOMAs). Grey-colored boxes highlight where ecological considerations take place to achieve ecosystem-based management (EBM).

activities-including land-based activities-that affect marine and coastal areas. The approach ensures that the ecosystem components crucial to maintaining ecosystem structure, functions, and environmental quality are not significantly affected by human activities and are maintained at appropriate temporal and spatial scales. EBM becomes operational when significant components (areas, species, properties) identified as management conservation priorities are translated into ecosystem objectives in IM plans for LOMAs to define the bounds within which sustainable development objectives must be set. This operational definition follows a series of guiding principles: (1) EBM is holistic and cross-disciplinary; (2) it is based on the best knowledge available; (3) it is a phased implementation process; (4) it is developed nationally and implemented subregionally, at LOMA scale; (5) it is area-based; (6) it is objective-based; and (7) it is applied within the broader context of IM, incorporating the precautionary approach and adaptive management principles.

In practice, ecological considerations need to be accounted for at each step of the integrated ocean management process to achieve a scientifically defensible EBM for the long-term conservation of marine ecosystems (Fig. 4). Science-based management tools specifically developed to support each of these steps form the EBM framework, summarized in Figure 5. The first step is to delineate marine ecological regions, those regions of the oceans that are naturally defined by large-scale ecological features and patterns of homogeneity. The intent is to use this ecological information layer for the establishment of LOMAs so that ecosystem considerations are taken into account in planning, decision making, and management of these areas (COS, 2002b). A three-day national workshop was held to delineate marine ecoregions in Canada's exclusive economic zone that encompasses three oceans
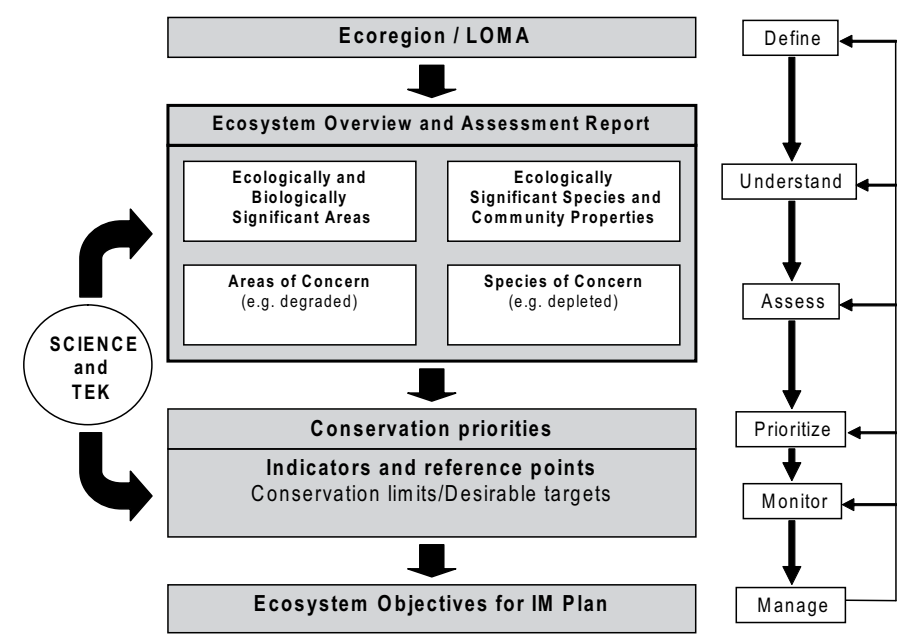

FIG. 5. Key elements and functions of the ecosystem-based management (EBM) framework developed to support integrated management (IM) in Canada's large ocean management areas (LOMAs).

(Powles et al., 2004). The pool of expert participants represented specialties in marine geology, physical oceanography, marine ecology, and biology. The delineation process was guided by previously identified science-based criteria (Table 1). The six ecoregions identified within the Canadian Arctic Ocean are described below. The Northern Labrador ecoregion, which strictly speaking belongs to the Atlantic Ocean, is also considered here because Arctic waters influence the area (Table 2).

Arctic Basin Ecoregion: Most of this area has depths greater than $1000 \mathrm{~m}$. The $200 \mathrm{~m}$ depth contour close to the adjacent High Arctic Archipelago Ecoregion has been used to draw the boundary between this and other ecoregions. The permanent ice that covers much of the area results in low primary productivity and the near absence of marine mammals and seabirds in the eastern part of the Arctic Basin. Limited information is available about benthic and fish communities.

Beaufort-Amundsen-Viscount Melville-Queen Maud Ecoregion: Most of the depths are less than $200 \mathrm{~m}$, with some very shallow waters in certain parts of the ecoregion. Pack ice characterizes the northern part, whereas seasonal ice predominates in the southern part. A characteristic of this region is the shallow waters between Viscount Melville Sound and Lancaster Sound. In the past, this feature was associated with a permanent plug of ice that was thought to act as a physical boundary in the westto-east movement of marine mammal populations (narwhals, belugas). Permanent ice begins at the northern edge of the ecoregion, which corresponds to a boundary for marine mammals and seabirds.

High Arctic Archipelago Ecoregion: This ecoregion is characterized by a high degree of enclosure due to the number of islands and narrow straits with relatively shallow waters. The entire region is covered by permanent ice, which explains its low primary productivity. The ecoregion is also characterized by a quasi-absence of top predators like marine mammals and seabirds. Seals are observed 
TABLE 1. Comparison of criteria used for delineating Canadian marine ecoregions and large marine ecosystems (LMEs).

\begin{tabular}{ll}
\hline \hline Canadian Ecoregions & LMEs \\
\hline $\begin{array}{l}\text { Geomorphological criteria } \\
\text { bathymetry, degree of enclosure, surface geology }\end{array}$ & Bathymetry \\
$\begin{array}{l}\text { Physical oceanography criteria } \\
\text { ice cover, freshwater influence, water temperature, water masses, currents, mixing and stratification }\end{array}$ & Hydrography \\
$\begin{array}{l}\text { Biological and ecological criteria } \\
\text { primary productivity, species distributions, populations structure, assemblages and communities }\end{array}$ & Productivity \\
\hline \hline
\end{tabular}

TABLE 2. Comparison of Canadian marine ecoregions and large marine ecosystems (LMEs) delineated in Canada's Arctic marine waters.

\begin{tabular}{ll}
\hline \hline Canadian Arctic Ecoregions & Arctic LMEs ${ }^{1}$ \\
\hline $\begin{array}{l}\text { Arctic Basin } \\
\text { Beaufort-Amundsen-Viscount Melville-Queen Maud }\end{array}$ & Beaufort Sea (\#55) and Arctic Archipelago (\#65) \\
\hline $\begin{array}{l}\text { High Arctic Archipelago } \\
\text { Lancaster Sound }\end{array}$ & Arctic Archipelago (\#65) \\
\hline $\begin{array}{l}\text { Hudson Complex } \\
\begin{array}{l}\text { Baffin Bay-Davis Strait } \\
\text { Northern Labrador }\end{array}\end{array}$ & Hudson Bay (\#63) \\
\hline \hline
\end{tabular}

${ }^{1}$ See Figure 3 for numbering of Arctic LMEs.

only in the southeastern part of the archipelago; species distribution of seals was used to determine the boundary between this ecoregion and the Lancaster Sound Ecoregion. There is a lack of information on benthic and fish species in this region.

Lancaster Sound Ecoregion: This ecoregion is characterized by depths below $1000 \mathrm{~m}$. It is a relatively enclosed area covered by seasonal ice. A big polynya starts at the mouth of Lancaster Sound and extends northward along the eastern coast of Ellesmere Island. The primary productivity of the region is relatively high, and abundant marine mammals (belugas, narwhals) and seabirds migrate seasonally to the eastern coast of Baffin Island.

Hudson Complex Ecoregion: This ecoregion, formed by Hudson Bay, James Bay, Foxe Basin, Hudson Strait, and Ungava Bay, is characterized by a high degree of enclosure. Water flow links the various parts of the ecoregion. Ice cover is seasonal, and two major polynyas have been observed in Hudson Bay and Foxe Basin. These relatively shallow waters are under the influence of important tides, and huge amounts of fresh water coming from the eastern part (Quebec) of Hudson Bay control mixing. Primary productivity is relatively high, mainly in coastal areas, and supports a diversity of fauna. Ecological assemblages of seabirds and marine mammals indicate that Hudson Bay, Foxe Basin, and Hudson Strait are three natural subecoregions, which may eventually be considered for planning and management purposes.

Baffin Bay-Davis Strait Ecoregion: This ecoregion has as its eastern boundary the continental shelf line, which separates it from offshore deep waters $(>1000 \mathrm{~m})$.
The ecoregion is covered by seasonal ice in winter and is influenced by tides and fresh waters. Deepwater temperatures are relatively colder than in the adjacent region to the south. Primary productivity is relatively high, mainly in waters surrounding the northern and eastern part of Baffin Island, and generally declines with distance from shore. Bottom water temperatures were used to identify the southern boundary of this ecoregion because there is clear evidence that this boundary corresponds to the distribution limits of numerous species of shrimp, groundfish, marine mammals, and seabirds.

Northern Labrador Ecoregion: The Hopedale Channel, a deep offshore channel perpendicular to the coast of Labrador, separates this ecoregion from the adjacent one to the south. The whole region is covered by ice seasonally, and waters are relatively warmer than in Baffin Bay. Three separate water masses parallel to the Labrador coast have been identified as coastal, shelf, and slope waters. Primary productivity is high, but the period of bloom is relatively short, resulting in a low annual average when compared to adjacent regions. The northern limit of this ecoregion corresponds to the northern limit of many temperate marine mammals, whereas its southern boundary coincides with the southern limit of Arctic belugas. This boundary is also a distribution limit for ranges of northern (Arctic) and southern (Atlantic) seabirds.

Delineation of ocean regions will always be somewhat arbitrary because marine ecosystems are nested systems, and what we would consider to be adjacent ecosystems do not always have clear gradients of discontinuity to serve as natural boundaries. Ecoregion boundaries are not 
definitive and should be revisited as more scientific knowledge is gathered, especially from data-poor areas like the Arctic Ocean. It is also important to note that for planning purposes and practical reasons, LOMA boundaries are drawn using a mix of ecological and administrative considerations (COS, 2002b).

Once an IM area is established, ocean managers and stakeholders need to be provided with the ecological information relevant to the implementation of EBM (Fig. 4; step 2). This approach implies that the status, trends, and health of the ecosystem are regularly reported and assessed, conservation priorities are identified, and ecosystem objectives are developed to further guide planning and decision making within the area. Management based on ecosystem considerations at a large scale (i.e., LOMAs) requires at least a minimum knowledge of what is in the ecosystem and how it works. However, the science support to management (i.e., monitoring, research, advice) should be targeted to priorities because it is not possible to know all about ecosystems and all relationships within and between ecosystems. Ecosystem priorities are those ecosystem components, features, and relationships that are ecologically significant and play an important role in maintaining ecosystem structure, functions, and processes.

The best available knowledge has to be incorporated from the outset of the planning process to inform subsequent steps (Fig. 5). This knowledge will come from two main sources: Western science (e.g., research, monitoring, modeling) and local and traditional ecological knowledge (TEK). The term TEK refers here to aboriginal knowledge and values about the natural environment and ethical codes governing the interactions between humans, animals, and the physical environment (White, 2006). Both TEK and Western ecosystem science have a key role in applying EBM approaches to the Arctic (Ayles et al., 2002; Cobb et al., 2005; Manseau et al., 2005). Eventually, science gaps will be identified and filled for further improvement of the EBM approach through an adaptive management process. In this respect, the 2007-08 International Polar Year (www.ipy.org) is building momentum around Arctic research, and great progress in this area is expected from these joint initiatives (Fortier and Fortier, 2006).

A nationally coordinated approach for the preparation of an EOAR for each LOMA has been developed to achieve step 2 in Figure 4 and standardize the reporting process between LOMAs. The EOAR is based on a preliminary review of the existing ecological knowledge. The first part of the report (the overview) is descriptive: it provides basic ecological information through a series of thematic chapters (Table 3), as well as an integrative chapter on ecosystem relationships and dynamics. The second part of the EOAR is an integrated ecosystem assessment based on the information compiled and reported in the overview; it reviews human activities and associated stressors that may have significant negative impacts on the ecosystem and assesses potential cumulative impacts from repetitive or various activities on the ecosystem. It analyzes and evaluates the actual conditions of ecosystem health, highlighting the areas and species that managers should pay attention to, either because of their key role in the ecosystem or because they have been affected by human activities. This ecological assessment is the main source of information to guide managers in setting conservation measures when managing activities in LOMAs.

National guidelines and criteria were developed to aid in identifying and mapping of EBSAs (DFO, 2004). Uniqueness, species aggregations, fitness consequences, resilience, and naturalness are criteria that would qualify an area as significant for the ecosystem. Similarly, national guidelines and criteria were developed to help identify "Ecologically Significant Species and Community Properties" (DFO, 2006): forage species, highly influential predators, nutrient importers and exporters, and structureproviding species are examples of significant species. Within a risk-based management context, managers have to give these significant areas, species, and properties a greater-than-usual degree of risk aversion when managing activities. Moreover, these species or areas may be sensitive and vulnerable to certain activities or stressors and may eventually need immediate protection or long-term conservation measures. There are several management options to ensure protection of sensitive or significant areas. MPAs and closure of fisheries are two of them. Invasive species and toxic phytoplankton that may cause significant damage to marine ecosystems will also require specific management measures to control their abundance and dissemination in the marine environment. Ecosystem features that have been affected by human activities to an extent that they can no longer play their structural or functional roles in the ecosystem are also identified and reported as "areas of concern" or "species of concern." Areas of concern are marine areas that may need targeted restoration (e.g., degraded habitats), rehabilitation measures (e.g., contaminated sites, eroded shoreline), or coordinated management strategies (e.g., areas of hypoxia or eutrophication). Species of concern are those for which a scientific assessment is essential and a recovery strategy and full protection may be required to ensure survival of the species or the population (e.g., endangered and threatened species listed under the Species-at-Risk Act, depleted stocks of commercial species).

Ecosystem objectives (EOs) are then developed around non-human components of the ecosystem described above and inserted into IM plans along with other objectives (Fig. 4; step 3). The EO-setting process has been guided at the national level to ensure consistency, but it is done at the regional (LOMA) level. The fine-tuning of management plans to address local or specific environmental issues will require EOs to become operational (i.e., site-, issue-, species- or sector-specific), which will be done by adding increasing specificity to EO statements. Two categories of EOs inform ecosystem-based integrated management: (1) objectives set for conservation purposes and (2) objectives targeting the desirable state of the ecosystem. 
TABLE 3. Comparison of frameworks developed for assessing and reporting on Canadian large ocean management areas (LOMAs) and large marine ecosystems (LMEs).

\begin{tabular}{|c|c|}
\hline Canadian LOMAs & LMEs \\
\hline Ecosystem Overview and Assessment Report (EOAR): & LME modular assessment: ${ }^{1}$ \\
\hline $\begin{array}{l}\text { To report on the status and trends of ecosystems, identify significant } \\
\text { components and ecosystem relationships, and assess impacts of human } \\
\text { activities on those components }\end{array}$ & To assess, analyze and monitor ecosystem-wide changes in topics of concern \\
\hline EOAR standard table of contents: & Modules and associated indicators: \\
\hline \multicolumn{2}{|l|}{$\begin{array}{l}\text { PART 1: Ecosystem overview: } \\
\text { 1. a) Geological system: } \\
\text { • Marine geology and geomorphology } \\
\text { - Sedimentology and sediment biogeochemistry }\end{array}$} \\
\hline $\begin{array}{l}\text { b) Oceanographic system: } \\
\text { - Atmosphere-ocean exchange } \\
\text { - Physical oceanography } \\
\text { - Physical-chemical properties of seawater }\end{array}$ & $\begin{array}{l}\text { 1. Productivity module: } \\
\text { - Photosynthetic activity } \\
\text { - Zooplankton diversity } \\
\text { - Oceanographic variability }\end{array}$ \\
\hline $\begin{aligned} \text { c) Biological system: } \\
\text { - Flora and fauna } \\
\quad \text { (planktonic, benthic, pelagic communities; } \\
\text { main taxonomic groups) } \\
\text { • Habitat use and functional areas } \\
\text { d) Ecosystem relationships: } \\
\cdot \text { Physical-biological linkages } \\
\text { - } \text { Biological interactions }\end{aligned}$ & $\begin{array}{l}\text { 2. Fish and fisheries module: } \\
\text { - Biodiversity } \\
\text { - Ichthyoplankton } \\
\text { - Invertebrates (shellfish) } \\
\text { - Demersal species } \\
\text { - Pelagic species, including marine mammals and seabirds }\end{array}$ \\
\hline \multicolumn{2}{|l|}{ PART 2: Ecological assessment: } \\
\hline $\begin{array}{l}\text { 2. a) Identification of key ecosystem features: } \\
\text { - Ecologically and biologically significant areas } \\
\text { - Ecologically significant species and community properties } \\
\text { b) Identification of impacted ecosystem components: } \\
\text { - Areas of concern } \\
\text { - Species of concern } \\
\text { c) Threats and impacts on ecosystem: } \\
\text { - Major activities and associated stressors } \\
\text { - Impacts of activities on key ecosystem features } \\
\text { - Global stressors and their local impacts } \\
\text { - Assessment of potential cumulative impacts } \\
\text { - Natural variability versus anthropogenic changes } \\
\text { d) Recommendation to management: } \\
\text { - Main environmental issues in the area } \\
\text { - Science gaps, uncertainties and reliability } \\
\text { - Identification of priorities for actions }\end{array}$ & $\begin{array}{l}\text { 3. Pollution and ecosystem health module: } \\
\text { - Water clarity } \\
\text { - Dissolved oxygen } \\
\text { - Coastal wetland loss } \\
\text { - Eutrophic conditions } \\
\text { - Sediment contamination } \\
\text { - Benthic index } \\
\text { - Fish tissue contaminants } \\
\text { - Multiple marine ecological disturbances }\end{array}$ \\
\hline
\end{tabular}

${ }^{1}$ The LME modular assessment is composed of five modules, but only the three modules that report on ecosystem features are described here. See Figure 1 for a description of all LME modules and indicators.

Conservation-oriented EOs are associated with appropriate ecological indicators and thresholds defining the biological limit of the system, those "conservation limits" that should never be compromised or exceeded to ensure a healthy ecosystem over time. Conservation limits are reference points that set the bounds of the system within which other management objectives should be established. Managers may also use them as "alarm points" when monitoring ecosystem status and trends through appropriate ecological indicators. Conservation objectives and limits are based solely on science and are developed from the identification of conservation priorities (DFO, 2007a).

The establishment of desirable state EOs combines ecological goals with social, cultural, and economic considerations. These EOs are identified as part of the IM process and allow ocean stakeholders, users, and planners to agree upon the state of the ecosystem they would like to reach in the future and to set targets against which the ecosystem status will be monitored over time. The necessary condition to achieve the sustainable use of ocean space and resources is to set those desirable targets within the bounds of conservation limits, so it is important to identify science-based conservation objectives and limits before setting social and economic objectives and targets. Once conservation limits and the targeted desirable state of the ecosystem are set, sound management-by-objectives will have to ensure that the actual state of the ecosystem, as measured through appropriate indicators, is varying within the safe zone towards target reference points, and moving away from limit reference points. Theoretically, it is expected that the farther away the current ecosystem status is from conservation limits and the nearer to targets, the greater the ecosystem goods and services and longterm socioeconomic benefits from ocean resources; this is 
the objective of sustainable fisheries. Desirable state objectives and targets may be set to minimize the environmental footprint of ocean activities (e.g., shipping, oil and gas) in a given LOMA. Targets also may be set to cope with species that are iconic or culturally important to local communities. A framework similar to EBM is being developed for setting social, cultural, and economic objectives, informed by the human use review and socioeconomic assessment. All IM partners will take part in setting these objectives, since they reflect "desirable state" targets from which societal benefits are expected. These objectives and targets have to be set within the bounds of sustainable development (Fig. 4; step 3).

Once inserted into an IM plan, EOs are monitored using indicators of marine environmental quality and ecosystem health. Lists of indicators have been developed from the review of numerous integrated coastal and ocean management initiatives worldwide (IOC, 2003; Sherman and Hempel, in press). The challenge is to select the smallest possible number of the most relevant indicators within effective, workable suites of indicators that meet the needs of integrated ocean management practitioners (IOC, 2006). For the Arctic, Western science and TEK are the main sources of information and may complement each other when the task is to develop marine environmental quality indicators and environmental signals of common interest for monitoring changing ecosystems (Cobb et al., 2005). One of the challenges is how best to use both sources of ecosystem knowledge for resource management. An example of such integration is the Government of Canada/ Inuvialuit co-management of fisheries (fish, marine mammals) in the western Arctic. The approach uses Western science and TEK to develop management plans for fisheries, which include resource monitoring and assessment (Ayles and Snow, 2002; Manseau et al., 2005).

To be effective, EBM must be adaptive and include a feedback mechanism (Fig. 5). During this iterative process, each step of the framework may be revisited when new information becomes available. The assessment of current knowledge and gaps will help to adjust planning and monitoring and provide decision makers with feedback on the effectiveness of their management actions to better inform future decisions.

\section{EBM AT THE SUBREGIONAL LEVEL: THE BEAUFORT SEA LOMA CASE STUDY}

\section{The Regional Environmental Context}

Oceans have been a dynamic growth sector for the Canadian economy over the last few decades. In the Canadian Arctic, transportation (largely seasonal and local), land mining, oil and gas exploration, ecotourism, and subsistence harvesting (i.e., fishing and hunting) all contribute to the ocean-based northern economy. Sensitivity to global warming and anticipated easier access to the
Canadian Arctic marine environment have led to great expectations for marine transportation through the Northwest Passage (Canadian Arctic Archipelago) and for exploiting the abundant natural resources (oil and gas, minerals, fisheries) in Canada's Arctic. Canada is facing a large challenge in this region. A better understanding of the marine ecosystem, cumulative impact assessments, long-term planning, and ecosystem-based integrated management of human activities will help face this challenge.

An integrated ocean management approach is being implemented in five priority management areas (OAP, 2005). The Beaufort Sea LOMA is the only one of these pilot areas located in Canada's Arctic waters. It is also the only LOMA in which a co-management regime exists: since the Inuvialuit Final Agreement for the Inuvialuit Settlement Region (ISR) was signed in 1984, the Inuvialuit and the federal government have shared resource management responsibilities in the land-claim area (Manseau et al., 2005).

\section{Delineating the Marine Ecoregion and Planning Area}

The biogeophysical characteristics of the Canadian western Arctic are relatively well known compared to those of other Canadian Arctic areas and have been the base for identifying ecoregions in both the land (Ayles and Snow, 2002) and the ocean (Powles et al., 2004). The boundaries for the Beaufort Sea LOMA were established by the Regional Coordination Committee, an interagency group that provides coordinated decision making, oversight, direction, and review for the development and implementation of an IM plan for the LOMA. The planning area encompasses the marine portion of the ISR (Fig. 6), which partly covers the Beaufort Sea Ecoregion and incorporates ecosystem-scale features, patterns, and trends. Covering $1514746 \mathrm{~km}^{2}$, it is the largest of Canada's five LOMAs.

\section{Understanding the Ecosystem}

An ecosystem overview was drafted using the best available information for the area, drawing on scientific knowledge and TEK (DFO, 2007b). This basic ecological information has been reviewed by co-managers, technical experts, partners, and communities. The report's content follows the standard table of contents developed for national consistency (Table 3), while taking into consideration regional specificities of Arctic ecosystems. This report is considered a "living" document and will be updated periodically as more is learned. A companion plainlanguage summary report has also been developed for distribution to the public (Schuegraf and Dowd, 2007).

\section{Assessing the State of the Ecosystem}

Within the assessment part of the EOAR (Table 3), sections dealing with ecologically significant areas and 


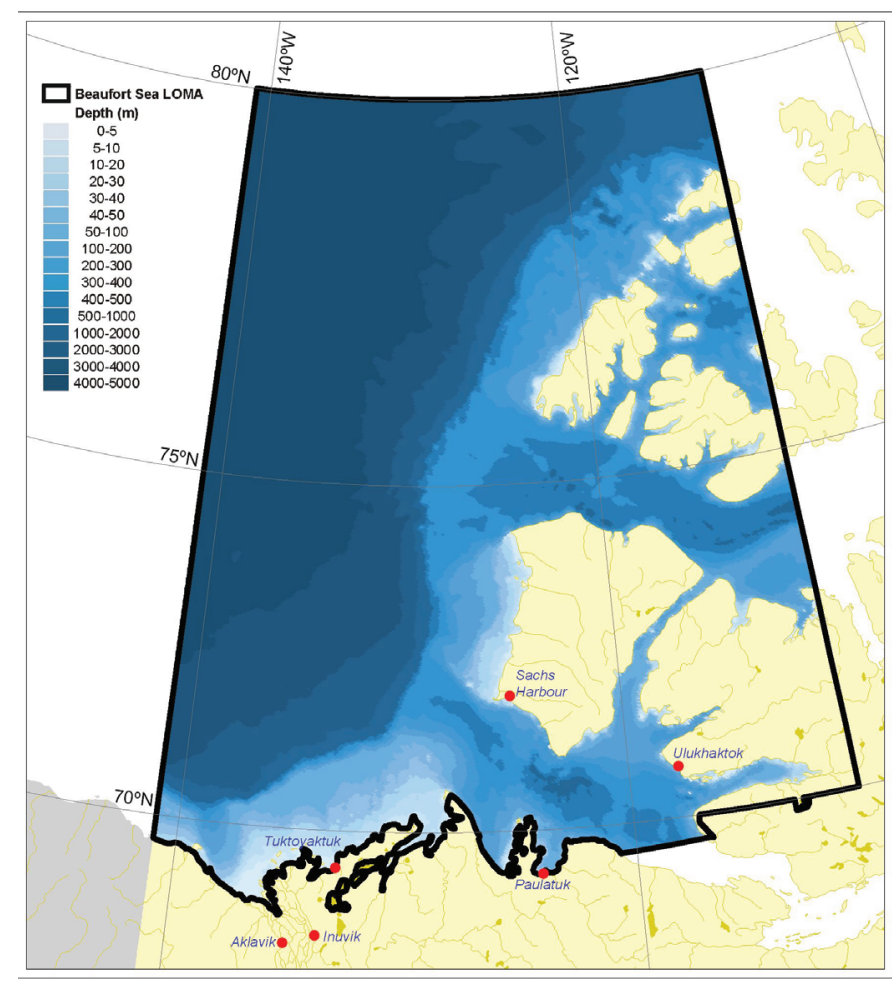

FIG. 6. The Beaufort Sea Large Ocean Management Area (LOMA).

species have involved significant partner engagement. A scientific workshop with experts from various fields and organizations documented what is known or hypothesized about the significance of areas and species of the Beaufort Sea, and a community workshop involving representatives from the six ISR communities from various Inuvialuit organizations also identified and mapped ecologically significant areas as known from TEK. Follow-up focus group sessions were also conducted in each of the communities with representatives from local organizations (e.g., youth, elders, hunters and trappers, renewable resources, parks), and TEK was once again documented. Findings from these consultations and previous work (e.g., community conservation plans, oral histories, and harvest studies) have been compiled. New information will be collected periodically to inform future assessments.

\section{Managing Human Activities}

The purpose of this work is to develop and implement an IM plan for the Beaufort Sea LOMA. The vision is to ensure that the Beaufort Sea ecosystem is healthy, safe, and prosperous for the benefit of current and future generations. Conservation objectives, along with social, cultural, and economic objectives, have been developed in consultation with communities, partners, and co-managers. Specifically, conservation objectives for the Beaufort Sea LOMA focus on maintaining marine biodiversity, productivity, and habitats. To ensure these objectives are being met, responsible authorities will have to identify indicators and thresholds and develop monitoring programs. Where possible, these objectives and indicators are building on previous or current initiatives, such as ISR community conservation plans, ongoing community-based and scientific monitoring programs, and the preliminary work on the proposed Tarium Niryutait MPA. The Beaufort Sea LOMA IM plan will identify priority objectives and responsible agencies. It will also outline strategies for achieving priority management objectives. Adaptive management will underpin the IM plan, so courses of action will be revised where objectives are not being met.

\section{Consulting and Governing}

To date, a governance structure consisting of a Regional Coordination Committee (RCC), a Planning Office, and a Beaufort Sea Partnership (BSP) has been established. The $\mathrm{RCC}$ is the primary governance body for the Beaufort Sea LOMA. It is an executive-level forum that formally engages federal regulators, territorial governments, and Inuvialuit organizations as co-management bodies for coordination, direction, and decision making in developing and implementing an IM Plan for the LOMA. Ultimately, the RCC will report to the Minister of Fisheries and Oceans, who is responsible for IM planning in Canada's oceans. The BSP is a broader multidisciplinary group composed of experts, stakeholders, industry, and interested parties. It serves as a network to identify new opportunities for collaboration and to prevent duplication of efforts by raising awareness of current and upcoming initiatives in the LOMA. A number of working groups have been formed within the BSP to advise the RCC on various issues: they include biophysical; consultation; geographic information; social, cultural, and economic; and traditional knowledge groups. The BSP builds on the work done by the working groups, considers questions formulated by the RCC, and also makes recommendations to the RCC.

\section{Challenges and Opportunities}

The Beaufort Sea is subject to the harsh Arctic climate, which is characterized by extreme seasonal variability in environmental factors such as ice cover, temperature range, winds, and river inflow (Carmack and Macdonald, 2002). Marine life is adapted to this extreme environment, but these conditions make the Beaufort Sea marine ecosystem vulnerable to human-induced stressors. From an EBM perspective, two overriding challenges for the Beaufort Sea LOMA exist: (1) a lack of knowledge of offshore areas and the entire area during the winter season, and (2) the global nature of the major ecosystem stressors: climate change and contaminants.

However, there are also many exciting opportunities and successful experiences. Examples are the creation of the first Oceans Act MPA in Canadian Arctic waters, the Government of Canada/Inuvialuit Fisheries Joint Management Committee for the co-management of several fish 
and marine mammal stocks, and collection of ecological knowledge through partnerships for scientific research and monitoring (e.g., the Beaufort Sea Habitat Mapping Program and the Beluga Harvest Monitoring Program). Relationships are being forged at all levels, from local to regional and international scales, through such venues as the Beaufort Sea Partnership, the Arctic Council, and the International Polar Year. Thus far, this inclusive, holistic and ecosystem-based approach to integrated ocean management has been well received and supported by the people of the Beaufort Sea region.

\section{COMPARATIVE ASPECTS: CANADA'S EBM FRAMEWORK AND ARCTIC LMES}

How does the EBM national framework implemented in Canada compare to the Arctic-wide LME framework in terms of consistency in scale, scope, and approach? We looked at four areas of interest for EBM to make this comparison as comprehensive as possible: (1) delineation criteria, (2) areas and boundaries, (3) assessment and reporting, and (4) planning and management.

\section{Delineation Criteria}

Scientific criteria were reviewed by a group of experts prior to delineating marine ecological regions in Canada's exclusive economic zone, including the Arctic Ocean. Taking account of knowledge gaps and data availability, experts proposed 13 criteria to support the delineation process, including key features for characterizing marine ecosystems (Table 1). Homogeneity patterns, gradients of discontinuities, and overlaps between criteria were highlighted during the process to identify ecoregion boundaries. The aim was to ensure that ecosystem-scale features and patterns would be captured in the management areas (e.g., LOMAs) established from this ecological delineation (Powles et al., 2004). The LME framework, on the other hand, is based on only four ecological criteria; however, the grouping of criteria is consistent between the Canadian ecoregion and LME frameworks (Table 1). More detailed criteria were used to support Canadian ecoregions because marine areas were delineated at smaller scales than LMEs. Certain criteria (e.g., surface geology, mixing and stratification, freshwater inputs) are likely more useful at the subregional (i.e., ecoregion) level than at a larger level (LMEs). These more detailed criteria were also helpful in identifying finer patterns of natural structures within ecoregions. The identification of ecoregion subunits may be useful for smaller-scale management.

\section{Areas and Boundaries}

Approximately four LMEs cover an area similar to that of the seven Canadian marine ecoregions (Table 2), reflecting the relatively smaller scale of the latter. The boundaries between the four LMEs and seven ecoregions match fairly well; the ecoregions are either equal to a LME (e.g., Hudson Complex) or nested within a larger LME (i.e., two ecoregions within one LME). The match indicates that the frameworks are complementary. For example, Canadian marine ecoregions as defined for domestic purposes could eventually serve as the ecological basis for identifying LME subunits if later needed.

\section{Assessment and Reporting}

Reporting frameworks for Canadian ecoregions or LOMAs (i.e., EOAR) and Arctic LMEs (i.e., LME modules and indicators) are comparable, although some details differ (Table 3). For example, the Productivity module for LMEs includes oceanography and biology, whereas physical oceanography and biology are described separately within the EOAR framework. However, these topics are integrated within a specific chapter on ecosystem relationships. The scope of the fourth LME module (not shown in Table 3 ) is to monitor and assess socioeconomic aspects. Although socioeconomic assessment is not part of the EOAR, socioeconomic considerations are taken into account in the IM approach in the Canadian context (Fig. 4). The main difference between the two frameworks resides in the outputs, rather than in the content. The EOAR framework has been specifically developed to inform the process of setting management objectives, whereas the LME modules primarily serve assessment and monitoring purposes (Table 3).

\section{Planning and Management}

The Oceans Act's IM program provides the governance structure to engage all parties in the management of ocean activities (Fig. 4). IM is the forum through which to prevent user conflicts or resolve them by applying best management practices and following key principles like EBM, sustainable development, the precautionary approach, conservation of marine resources, shared responsibilities, flexibility, and inclusiveness (COS, 2002b). Similarly, the LME governance module focuses on adaptive management and stakeholder participation. Canada's IM is built upon a series of management objectives dealing with ecological, social, cultural, and economic aspects. These management objectives will provide strategic directions for LOMA planners and decision makers. The LME TDA process similarly identifies consensus priorities from analysis and ranking of water-related resource issues, their environmental and socioeconomic impacts, immediate and root causes, and possible remediation actions (Fig. 2). Upon implementation, the LME process calls for the development of an SAP to coordinate national and regional commitments to policy, legal and institutional reforms, and investments to remedy root causes identified in the TDA and to close gaps in ecosystem assessment and monitoring. An ecosystem-based assessment and 
management strategy for TDA and SAP is then implemented, and progress is tracked as shown in Figure 2.

A variety of management options are available to advance EBM in Canadian LOMAs. Ocean managers have to select the most appropriate options, and this selection will depend on the activities to be managed and the environmental issues to be addressed. For example, fishery closures, marine environmental quality standards, designation of MPAs, full protection of species-at-risk, and industry codes of practice are management options that help conserve or restore marine ecosystems. Whatever the management tools applied, ecosystem objectives, including those objectives set for conservation, will have to be met. On the other hand, if ecological indicators show that an ecosystem objective will not be met under a current management regime, pre-determined management actions or corrective measures will be triggered. Monitoring of ecosystem objectives and ecological indicators is also essential to assessing the effectiveness of management actions over time and reporting on the status and trends of marine ecosystems in the management area.

\section{CONCLUSIONS}

As ecosystem-based, integrated management becomes the primary approach to meeting sustainable development objectives in coastal and ocean areas, more and more countries (including Arctic circumpolar countries) will incorporate this approach into their national legislation and policy instruments for managing activities and resources in marine areas under their jurisdiction. We anticipate a variety of initiatives and approaches led by different governments and implemented by different governance structures. Optimally, national approaches will be compatible and coherent with each other, although not necessarily similar. Dealing with this variety at an Arctic-wide level will be a challenge.

Diversity will not be a problem if there are common goals, objectives, and guiding principles. This is where an intergovernmental forum like the Arctic Council is so important. Through its programs and working groups, the Arctic Council promotes cooperation, coordination, and interaction among circumpolar countries (member states) and Arctic indigenous people (www.arcticportal.org). It provides the high-level governance structure that is required to deal with international shared waters and inform and advise governments on Arctic issues. No binding formal decisions result from the work of the Arctic Council. However, its initiatives are supported by a number of experts involved in the working groups and by senior officials representing each Arctic country. Member states have a moral obligation to promote and respect the Arctic Council's principles, and eventually adopt the same approaches and practices in their national policy frameworks. For example, the Arctic Council's PAME working group will now select ecological indicators to monitor and assess the state of Arctic LMEs and produce a "state of the Arctic" report. This information will be used to advise governments of circumpolar nations, and these in turn may incorporate the information into national policy instruments and best management practices.

TEK has a key role to play in EBM in the Arctic because it provides incommensurable historical and current in-situ observations to fill science gaps and confirm scientific theories or predictions. Western science, based on strong support by human resources, facilities, equipment and technologies, may provide a more regional or even global picture of the status of the Arctic environment. Modeling and simulations should help northern populations and coastal communities to refine adaptation strategies so they can cope with changing environmental conditions. Collective knowledge on marine ecosystems will become more integrated into long-term ocean planning and more relevant to management and decision making if it is shared among all bodies (Arctic countries, governments, northern communities) and people (scientists, managers, stakeholders) who are engaged in addressing Arctic issues. A thematic network like ArcticNet (www.arcticnet. ulaval.ca) is a good start to establishing such connections. Thus, we can expect a more informed and effective ecosystem-based, integrated management to be a solid basis for achieving sustainable development in the Arctic. Carmack and Macdonald (2002) asked about our ability to protect and manage the living resources of the Arctic. EBM, including shared collective knowledge, is a promising approach that is certainly part of the answer.

We can see great potential for cross-level interactions between the two spatial frameworks considered in this study. In the Arctic, they will operate in complementary ways. The Arctic-wide LME framework will (1) take advantage of already existing approaches implemented at national or subregional levels and (2) provide the "umbrella structure" to facilitate coordination in shared waters, identify and promote best practices (e.g., EBM pilots), develop common tools, and provide opportunities for collaboration in other parts of the Arctic. We recognize that this analysis is fragmentary. EBM is just moving from concept to implementation in the Arctic, so benefits from this approach are still largely unrealized. However, the timing for EBM implementation is opportune, as the Arctic is experiencing major change and there are growing concerns about its future. Having a multi-level spatial framework, science-based management tools, and a governance structure available to ocean managers will allow EBM to become operational in the near future and will help to address the complex environmental issues facing the Arctic. As we implement EBM, further analytical studies will be required to evaluate the benefits of a multi-level approach. From an ocean management perspective, it would also be interesting to consider jurisdictional, temporal, and knowledge scales, as well as "cross-scale" and "cross-level" interactions (Cash et al., 2006). 


\section{ACKNOWLEDGEMENTS}

The work on Arctic Large Marine Ecosystems is part of the Arctic Council's Protection of the Arctic Marine Environment (PAME) work plan and Oil \& Gas Assessment led by the Arctic Council's Assessment and Monitoring working group. This article is a synthesis of the presentations delivered during the thematic session on Ecosystem-Based Management (EBM) in the Arctic held in Tuktoyaktuk in August 2006. We thank C. Bookless, who helped organize the session, and D. Rosenberg, who provided helpful comments on the draft manuscript. We are grateful to the many experts who helped over the years to develop the EBM framework for integrated ocean management in Canada.

The views expressed in this paper do not necessarily reflect the views of the Government of Canada.

\section{REFERENCES}

ACIA (ARCTIC CLIMATE IMPACT ASSESSMENT). 2004. Impacts of a warming Arctic. Cambridge, United Kingdom: Cambridge University Press. 139 p.

AMSA (ARCTIC MARINE SHIPPING ASSESSMENT). 2006. Arctic marine shipping assessment - The Arctic Council's response to changing marine access. Progress report October 2006. Akureyri, Iceland: Protection of the Arctic Marine Environment (PAME) International Secretariat. $12 \mathrm{p}$.

ANON. 2002. Rent og rikt hav. Sortingsmelding nr 12 (20012002). (Translated into English: Protecting the riches of the sea; Government white paper to Parliament.) Oslo, Norway: Norwegian Ministry of the Environment. 104 p.

- 2006. Integrated management of the marine environment of the Barents Sea and the sea areas off the Lofoten Islands. Report No. 8 to the Storting (2005-2006). Oslo, Norway: Norwegian Ministry of the Environment. 144 p.

ARCTIC COUNCIL. 2004. Arctic Marine Strategic Plan. Akureyri, Iceland: Protection of the Arctic Marine Environment (PAME) International Secretariat. 13 p.

AYLES, G.B., and SNOW, N.B. 2002. Canadian Beaufort Sea 2000: The environmental and social setting. Arctic 55(Suppl.1): 4-17.

AYLES, G.B., BELL, R., and FAST, H. 2002. The Beaufort Sea Conference 2000 on the Renewable Marine Resources of the Canadian Beaufort Sea. Arctic 55(Suppl. 1):iii-v.

BEHRENFELD, M., and FALKOWSI, P.G. 1997. Photosynthetic rates derived from satellite-based chlorophyll concentration. Limnology and Oceanography 42(1):1-20.

BRIGHAM, L., and ELLIS, B., eds. 2004. Proceedings of the Arctic Marine Transport Workshop, 28-30 September 2004, Scott Polar Research Institute, Cambridge University. Anchorage, Alaska: Institute of the North, Arlington, Virginia: U.S. Arctic Research Commission, and Oslo: International Arctic Science Committee. 18 p.

CARMACK, E.C., and MACDONALD, R.W. 2002. Oceanography of the Canadian Shelf of the Beaufort Sea: A setting for marine life. Arctic 55(Suppl. 1):29-45.
CASH, D.W., ADGER, W., BERKES, F., GARDEN, P., LEBEL, L., OLSSON, P., PRITCHARD, L., and YOUNG, O. 2006. Scale and cross-scale dynamics: Governance and information in a multilevel world. Ecology and Society 11(2): 8. [online]: http:/ /www.ecologyandsociety.org/vol11/iss2/art8/.

CBD (CONVENTION ON BIOLOGICAL DIVERSITY). 2000. Decision adopted by the Conference of the Parties to the Convention on Biological Diversity at its fifth meeting - Decision V/6: Ecosystem Approach and Annex. UNEP/CBD/COP/5/23. Nairobi: United Nations Environment Programme/Convention on Biological Diversity. 7 p.

CLARKE, A., and HARRIS, C.M. 2003. Polar marine ecosystems: Major threats and future change. Environmental Conservation 30(1): $1-25$.

COBB, D., BERKES, M.K., and BERKES, F. 2005. Ecosystembased management and marine environmental quality in northern Canada. In: Berkes, F., Huebert, R., Fast, H., Manseau, M., and Diduck, A., eds. Breaking ice: Renewable resource and ocean management in the Canadian North. Calgary, Alberta: University of Calgary Press. 71-93.

COS (CANADA'S OCEANS STRATEGY). 2002a. Canada's Oceans Strategy. Ottawa: Fisheries and Oceans Canada. 33 p.

. 2002b. Policy and operational framework for integrated management of estuarine, coastal and marine environment in Canada. Ottawa: Fisheries and Oceans Canada. 36 p.

DFO (FISHERIES AND OCEANS CANADA). 2004. Identification of ecologically and biologically significant areas. Canadian Science Advisory Secretariat, Ecosystem Status Report 2004/ 006. Ottawa: Fisheries and Oceans Canada. 15 p.

2006. Identification of ecologically significant species and community properties. Canadian Science Advisory Secretariat, Science Advisory Report 2006/041. Ottawa: Fisheries and Oceans Canada. 24 p.

. 2007a. Guidance document on identifying conservation priorities and phrasing conservation objectives for Large Ocean Management Areas. Canadian Science Advisory Secretariat, Science Advisory Report 2007/010. Ottawa, Ontario: Fisheries and Oceans Canada. 13 p.

- 2007b. Beaufort Sea Large Ocean Management Area: Ecosystem overview and assessment report. Winnipeg, Manitoba: Fisheries and Oceans Canada. 196 p.

DUDA, A.M., and SHERMAN, K. 2002. A new imperative for improving management of large marine ecosystems. Ocean and Coastal Management 45:797-833.

FORTIER, M., and FORTIER, L. 2006. Canada's Arctic: Vast, unexplored and in demand. Journal of Ocean Technology 1(1): $1-7$.

GARIBALDI, L., and LIMONGELLI, L. 2003. Trends in oceanic captures and clustering of large marine ecosystems: Two studies based on the FAO capture database, as reported to the FAO by official national sources. FAO Fisheries Technical Paper 435. $71 \mathrm{p}$.

GESAMP (IMO/FAO/IOC-UNESCO/WMO/WHO/IAEA/UN/ UNEP JOINT GROUP OF EXPERTS ON THE SCIENTIFIC ASPECTS OF MARINEENVIRONMENTALPROTECTION). 2001. Protecting the oceans from land-based activities - Land- 
based sources and activities affecting the quality and uses of marine, coastal and associated freshwater environment. GESAMP Reports and Studies No. 71. The Hague, The Netherlands: GESAMP and Advisory Committee on Protection of the Sea. $162 \mathrm{p}$.

IOC (INTERGOVERNMENTAL OCEANOGRAPHIC COMMISSION). 2003. A reference guide on the use of indicators for integrated coastal management. Manuals and Guides 45, ICAM Dossier No. 1. Paris: Intergovernmental Oceanographic Commission of UNESCO, in collaboration with Fisheries and Oceans Canada, University of Delaware Center for the Study of Marine Policy, and U.S. National Oceanic and Atmospheric Administration. 127 p.

. 2006. A handbook for measuring the progress and outcomes of integrated coastal and ocean management. Manuals and Guides 46, ICAM Dossier No. 2. Paris: Intergovernmental Oceanographic Commission of UNESCO, in collaboration with Fisheries and Oceans Canada, University of Delaware Center for the Study of Marine Policy, and U.S. National Oceanic and Atmospheric Administration. 155 p.

MAGEAU, C., VANDERZWAAG, D., and FARLINGER, S. 2005. Oceans policy: A Canadian case study. In: TOPS $2005-$ The Ocean Policy Summit, Lisbon, Portugal, 10-14 October, 2005. The Global Forum on Oceans, Coasts, and Islands. 24 p. Available at: www.globalforum.org/tops2005/pdf/Canada.pdf.

MANSEAU, M., PARLEE, B., and AYLES, G.B. 2005. A place for traditional ecological knowledge in resource management. In: Berkes, F., Huebert, R., Fast, H., Manseau, M., and Diduck, A., eds. Breaking ice: Renewable resource and ocean management in the Canadian North. Calgary, Alberta: University of Calgary Press. 141-164.

McLEOD, K.L., LUBCHENCO, J., PALUMBI, S.R., and ROSENBERG, A.A. 2005. Scientific consensus statement on marine ecosystem-based management. Signed by 217 academic scientists and policy experts with relevant expertise and published by the Communication Partnership for Science and the Sea. Available at http://compassonline.org.

OAP (OCEANS ACTION PLAN). 2005. Canada's Oceans Action Plan. Ottawa: Fisheries and Oceans Canada. 20 p.

OCEANS ACT. 1996. Statutes of Canada, c. 31, proclaimed 20 December 1996.

OLSEN, E., GJØSÆTER, H., RØTTINGEN, I., DOMMASNES, A., FOSSUM, P., and SANDBERG, P. 2007. The Norwegian ecosystem-based management plan for the Barents Sea. ICES Journal of Marine Science 64:599-602.
POWLES, H., VENDETTE, V., SIRON, R., and O'BOYLE, R. 2004. Proceedings of the Canadian Marine Ecoregions Workshop. Canadian Science Advisory Secretariat, Proceedings Series 2004/016. Ottawa: Fisheries and Oceans Canada. 47 p.

RAPPORT, D., COSTANZA, R., EPSTEIN, P.R., GAUDET, C., and LEVINS, R., eds. 1998. Ecosystem health. Malden, Massachusetts: Blackwell Science Inc. 372 p.

SCHUEGRAF, M., and DOWD, P. 2007. Understanding the Beaufort Sea ecosystem: Plain language summary of the Beaufort Sea ecosystem overview and assessment report. Winnipeg, Manitoba: Fisheries and Oceans Canada. 19 p.

SHERMAN, K. 1994. Sustainability, biomass yields, and health of coastal ecosystems: An ecological perspective. Marine Ecology Progress Series 112:277-301.

SHERMAN, K., and HEMPEL, G., eds. In press. The UNEP Large Marine Ecosystem Report: A perspective on changing conditions in LMEs of the world's regional seas. UNEP Regional Seas Report and Studies No. 182. Nairobi, Kenya: United Nations Environment Programme. $650 \mathrm{p}$.

SKJOLDAL, H.R., ed. 2004. The Norwegian Sea ecosystem. Trondheim, Norway: Institute of Marine Research and Tapic Academic Press. 559 p.

UNEP (UNITED NATIONS ENVIRONMENT PROGRAMME). 2006. The state of the marine environment-Regional assessments - Chapter 8: Arctic Ocean. The Hague, The Netherlands: UNEP/ GPA Coordination Office, UNEP/Global Programme of Action for the Protection of the Marine Environment from Land-based Activities. 193-212.

USCOP (UNITED STATES COMMISSION ON OCEAN POLICY). 2004. An ocean blueprint for the 21st century: Final report. Washington, D.C.: U.S. Commission on Ocean Policy. $522 \mathrm{p}$.

USEO (UNITED STATES EXECUTIVE OFFICE). 2004. Executive Order 121704 Committee on Ocean Policy. Washington, D.C.: U.S. Executive Office.

USOAP (UNITED STATES OCEAN ACTION PLAN). 2004. U.S. Ocean Action Plan. Washington, D.C.: Office of the President of the United States. 39 p.

WANG, H. 2004a. Ecosystem management and its application to large marine ecosystems: Science, law, and politics. Ocean Development and International Law 35(1):41-74.

- 2004b. An evaluation of the modular approach to the assessment and management of large marine ecosystems. Ocean Development and International Law 35(3):267-286.

WHITE, G. 2006. Cultures in collision: Traditional knowledge and Euro-Canadian governance processes in northern land-claim boards. Arctic 59(4):401-414. 